\title{
Levels of Resilience and Stress Among Secondary School Students During the COVID-19 Pandemic
}

Norulhuda Sarnon, Ngai Suet Li, Nor Jana Saim \& Salina Nen

To Link this Article: http://dx.doi.org/10.6007/IJARBSS/v12-i1/12106

DOI:10.6007/IJARBSS/v12-i1/12106

Received: 23 November 2021, Revised: 25 December 2021, Accepted: 10 January 2022

Published Online: 20 January 2022

In-Text Citation: (Sarnon et al., 2022)

To Cite this Article: Sarnon, N., Li, N. S., Saim, N. J., \& Nen, S. (2022). Levels of Resilience and Stress Among Secondary School Students During the COVID-19 Pandemic. International Journal of Academic Research in Business and Social Sciences, 12(1), $866-877$.

Copyright: @ 2022 The Author(s)

Published by Human Resource Management Academic Research Society (www.hrmars.com)

This article is published under the Creative Commons Attribution (CC BY 4.0) license. Anyone may reproduce, distribute, translate and create derivative works of this article (for both commercial and non0-commercial purposes), subject to full attribution to the original publication and authors. The full terms of this license may be seen at: http://creativecommons.org/licences/by/4.0/legalcode

Vol. 12, No. 1, 2022, Pg. $866-877$

Full Terms \& Conditions of access and use can be found at http://hrmars.com/index.php/pages/detail/publication-ethics 


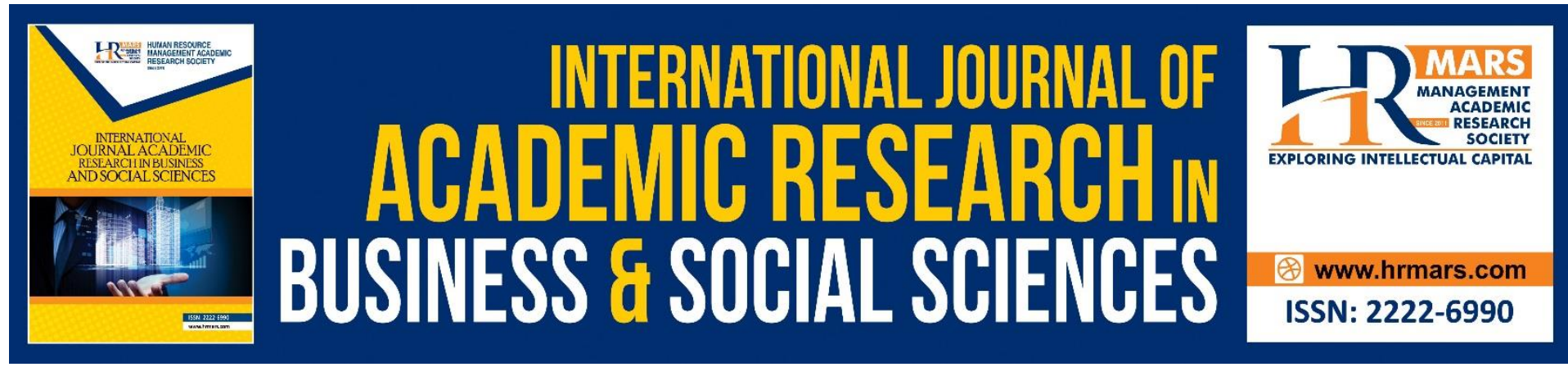

\title{
Levels of Resilience and Stress Among Secondary School Students During the COVID-19 Pandemic
}

\author{
Norulhuda Sarnon, Ngai Suet Li, Nor Jana Saim \& Salina Nen \\ Social Work Program, Center for Research in Psychology and Human Well-Being, \\ Faculty of Social Science and Humanities, Universiti Kebangsaan Malaysia, \\ 43600 Bangi, Selangor, Malaysia \\ Corresponding Author: norul@ukm.edu.my
}

\begin{abstract}
The spread of the COVID-19 virus has changed learning processes and can put students under a lot of stress. If students lack of resilience, the stress they are experiencing have an adverse effect on their mental health. The goal of this study was to look at how resilient and stressed school children were during COVID-19 transmission, as well as the variations in resilience and stress between male and female students. A total of 180 adolescents from grades one to five were involved in this study. This research utilizes quantitative approaches, with data obtained by questionnaire distribution. SPSS Version 26 was used to analyse data received from 180 respondents via questionnaires. According to the findings of a Pearson correlation analysis, there is a significant relationship between school students' resilience and stress levels during the COVID-19 pandemic outbreak. Meanwhile, the T -Test revealed that throughout the pandemic, there was a substantial mean difference in stress levels between male and female students aged 13 to 19. Finally, the study's findings have significant implications for parents, schools, and policymakers in terms of empowering adolescents to manage stress. Future study suggestions are also encouraged.
\end{abstract}

Keyword: Stress, Resiliency, Students, COVID-19, Secondary School

\section{Introduction}

Due to the spread of the COVID-19 pandemic, students, particularly teenagers, have had to adapt to new online learning patterns such as the Home Learning and Teaching Process (PdPDR). Furthermore, the COVID-19 pandemic has an impact on the administration of public tests, specifically the School Achievement Test. This year, the Primary (UPSR) and Form Three Assessment (PT3) had to be cancelled. Other general exams, such as Sijil Pelajaran Malaysia (SPM), Sijil Vokasional Malaysia (SVM), Sijil Tinggi Pelajaran Malaysia (STPM), and Sijil Tinggi Agama Malaysia (STAM), have been postponed until the following year. Adolescent or students who are stated to be in the process of gaining resilience may experience stress as a result of such big changes. Students may feel lonely when using online learning methods, especially during movement control periods. According to Zaiton and Balan (2014)'s research, there is a negative relationship between self-resilience and self-loneliness among IPT students $(r=0.166)$. Only the emotional resilience construct, as opposed to the other three 
constructions, self-strength resilience, self-management resilience, and optimistic resilience, exhibited a significant adverse correlation with loneliness.

The Morales-Rodrguez (2021) study found that university students aged 18 to 25 in Spain were in a poor level of resilience during the COVID-19 pandemic epidemic, with the greatest resilience score for the study group being only 98 points. Furthermore, the findings of the study indicate the existence of a significant correlation between resilience and coping strategies. According to Sundarasen et al (2020), the results of Chi-Square Test analysis revealed that during the period of the Movement Control Order, demographic variables such as gender, age, ethnic group, type of university, field of study, and accommodation (living arrangement) showed a significant relationship at the significance level of 0.25 percent (PKP). Meanwhile, regression analysis revealed a strong association between high levels of anxiety and female gender, age under 18, age between 19 and 25 years, pre-university education level, field of management studies, and living alone. Furthermore, the findings of this study revealed that adolescents aged 17 to 18 years old experienced high levels of anxiety during the period of the study.

Malaysian researcher namely Amran \& Jamaludin (2021) revealed that adolescents faced four main themes of experience during the COVID-19 pandemic: Alteration of sleep patterns, stress-related fatigue, dysfunctional eating patterns and lack of physical activity. This firsthand experience shows that knowledge and skills of adolescents' behavioral practices during outbreak deserves attention. Most children who participate in online learning are given computers or smartphones by their parents to make it easier for them to access the material. However, it has negative consequences, as a study by Hilwa, Nur Farah Jasmeen and Daniella Maryam (2020) discovered that adolescents' sleep patterns are readily disrupted, even if they are already addicted to cellphones. Adolescents must be resilient in this situation. Given the mild findings of a study on teenagers in protective institution by Sukor, Nur Saadah, and Ezarina (2019), this situation is concerning. However, what about students' stress and resilience levels throughout this COVI19 pandemic season? Enba et al (2021) found that students were psychologically influenced and displayed depression symptoms. As a result, it is vital to conduct study after study in order to secure the well-being of today's students.

\section{Method}

Design

Researchers used a quantitative cross-sectional survey design (cross-sectional survey) in this study. Chua (2011) defines survey research as a non-experimental research technique in which information on the study subject is collected via a questionnaire form.

\section{Sample}

At this study, the researcher used a stratified random selection technique to choose a group of form 1 to 5 school children in secondary schools in the Alor Gajah region of Melaka. This study had a sample size of 180 participants. This is because no other scientific study on the measurement of teenage stress and resilience has been conducted in this district's secondary schools, particularly during the COVID-19 pandemic outbreak.

\section{Questionnare}

Resiliency Scale

The Questionnare contains 25 questions constructed by Wagnild and Young (1993) related to the resilience scale (RS-25) which includes two main aspects, namely personal competence 
and acceptance of self and life. Self-reliance, perseverance, resolve, tenacity, not easily discouraged, and reasonable personalities are examples of personal competency.There were 17 questions in total for this element. Self-acceptance and life, on the other hand, relates to the ability to adapt, balance, flexibility, and a balanced outlook on life. This feature was assessed using a total of eight Wagnild and Young (1993) resilience scale questions. The 7Point Likert Measure was included in the 25 -item resilience scale developed by Wagnild and Young (1993).

\section{Stess Scale}

This Questionnare comprises ten items relating to the Perceived Strees Scale that were created by Cohen, S. et al. (1983). The Perceived Stress Scale (PSS) is a psychological tool that assesses a person's stress perceptions. PSS can determine the degree to which a circumstance in a person's life is considered stressful. PSS was chosen as a stress level measurement method in this study by the researcher because the questions were simple to understand. The 5 Point Likert Scale is the scale used in the PSS.

\section{Result}

\section{Demography}

This study involved 68 (37.80\%) of male respondents, and 112 (62.80\%) of female respondents. A total of $30(16.70 \%)$ of the 180 students who took part in the study, were aged 13 or older. There were $31(17.20 \%)$ respondents age14-year-old. The number of 15 year-old age group respondents was 35, (19.40\%). In addition, 29 (16.10\%) respondents were 16 years old when they took part in the survey. Furthermore, a total of $23(12.80 \%)$ of the 17 year-olds respondents, took part in the survey and none of the 180 responders were under the age of 18. 
Table 1: Demography of the respondents

\begin{tabular}{lll}
\hline & Total & $\begin{array}{l}\text { Percent } \\
\text { (\%) }\end{array}$ \\
\hline Gender & & \\
\hline Male & 68 & 37.8 \\
Female & 112 & 62.2 \\
\hline Age & & \\
\hline 13 years old & 30 & 16.7 \\
14 years old & 31 & 17.2 \\
15 years old & 35 & 19.4 \\
16 years old & 29 & 16.1 \\
17 years old & 23 & 12.8 \\
18 years old & 0 & 0 \\
19 years old & 32 & 17.8 \\
\hline Ethnic & & \\
\hline Malay & 12 & 6.7 \\
Chinese & 141 & 78.3 \\
India & 25 & 13.9 \\
Others & 2 & 1.1 \\
\hline Residential Area & & \\
\hline Urban & 71 & 39.4 \\
Rural & 109 & 60.6 \\
\hline Total Household Income & & \\
\hline Less than RM4500 & & \\
RM4501 - RM10000 & 98 & 54.4 \\
More than RM10001 & 69 & 38.3 \\
\hline Number of Family Members & 13 & 7.2 \\
\hline Less than 4 persons & & \\
$4-8$ persons & 187.1 \\
More than 8 persons & & 1.7 \\
\hline TOTAL & & \\
\hline & & \\
\hline
\end{tabular}

Malays account for $12(6.70 \%)$ of the total respondents, whereas Indians account for 25 (13.90\%) of the total respondents. A total of 71 people (39.40\%) of the 180 respondents, are residents of urban regions. Meanwhile, the remaining respondents, 109 (60.60\%), live in the rural area. Apart from that, a total of 98 respondents (54.40\%) belong to the B40 category, which has a total household income of less than RM4500. Meanwhile, 69 respondents (38.30\%) belong to the M40 category, which has a monthly family income of RM4501 to RM10000. Only 13 respondents (7.20\%) fall into the T20 category, which has a total household income of greater than RM10001. The majority of respondents $(87.20 \%)$ had four to eight family members, with 157 (87.20\%) having four to eight family members. Following that, 20 respondents (11.10\%) hailed from families with fewer than four members. Only three people $(1.70 \%)$ had more than eight relatives. Table 1 presents the study's demographic data in terms of gender, age, ethnicity, household income, home area, and family size. 


\section{Resiliency}

According to the findings of the study, 50.56 percent (91 people) of the respondents have a moderate level of resilience, while 88 people (48.89 percent) have a high level of resilience. Only one participant ( 0.56 percent) in a group of 180 exhibited a lack of resilience. The results of the analysis also found that the mean value of resilience of respondents in this study is 126.33. The level of the respondents' resilience is shown in the table.

Table 2: Level of Resiliency

\begin{tabular}{llll}
\hline Resiliency & Frequency & Percent (\%) & Min \\
\hline Low & 1 & 0.56 & \\
Moderate & 91 & 50.56 & \\
High & 88 & 48.89 & \\
Total & $\mathbf{1 8 0}$ & $\mathbf{1 0 0 . 0 0}$ & $\mathbf{1 2 6 . 3 3}$ \\
\hline
\end{tabular}

Table 3: Minimum value, maximum value, mean and standard deviation of resilience

\begin{tabular}{|c|c|c|c|c|c|}
\hline No & Item & Minimum & Maximum & Min & SD \\
\hline 1 & $\begin{array}{l}\text { When I make plans I } \\
\text { follow through with them. }\end{array}$ & 1 & 7 & 5.23 & 1.434 \\
\hline 2 & $\begin{array}{l}\text { I usually manage one way } \\
\text { or another. }\end{array}$ & 1 & 7 & 4.94 & 1.183 \\
\hline 3 & $\begin{array}{l}\text { I am able to depend on } \\
\text { myself more than anyone } \\
\text { else. }\end{array}$ & 1 & 7 & 4.97 & 1.406 \\
\hline 4 & $\begin{array}{l}\text { Keeping interested in } \\
\text { things is important to me. }\end{array}$ & 1 & 7 & 5.59 & 1.421 \\
\hline 5 & $\begin{array}{l}\text { I can be on my own if I } \\
\text { have to. }\end{array}$ & 1 & 7 & 5.84 & 1.787 \\
\hline 6 & $\begin{array}{l}\text { I feel proud that I have } \\
\text { accomplished things in } \\
\text { life. }\end{array}$ & 1 & 7 & 5.36 & 1.327 \\
\hline 7 & $\begin{array}{l}\text { I usually take things in my } \\
\text { stride. }\end{array}$ & 1 & 7 & 4.96 & 1.376 \\
\hline 8 & I am friends with myself. & 1 & 7 & 4.63 & 2.000 \\
\hline 9 & $\begin{array}{l}\text { I feel that I can handle } \\
\text { many things at a time. }\end{array}$ & 1 & 7 & 4.37 & 1.520 \\
\hline 10 & I am determined. & 1 & 7 & 5.01 & 1.386 \\
\hline 11 & $\begin{array}{l}\text { I seldom wonder what the } \\
\text { point of it all is. }\end{array}$ & 1 & 7 & 4.12 & 1.488 \\
\hline 12 & $\begin{array}{l}\text { I take things one day at a } \\
\text { time. }\end{array}$ & 1 & 7 & 4.97 & 1.491 \\
\hline 13 & $\begin{array}{l}\text { I can get through difficult } \\
\text { times because I've } \\
\text { experienced difficulty } \\
\text { before. }\end{array}$ & 1 & 7 & 5.13 & 1.228 \\
\hline 14 & I have self-discipline. & 1 & 7 & 5.31 & 1.317 \\
\hline
\end{tabular}




\begin{tabular}{|c|c|c|c|c|c|}
\hline 15 & I keep interested in things. & 1 & 7 & 5.29 & 1.393 \\
\hline 16 & $\begin{array}{l}\text { I can usually find } \\
\text { something to laugh about. }\end{array}$ & 1 & 7 & 4.99 & 1.521 \\
\hline 17 & $\begin{array}{l}\text { My belief in myself gets } \\
\text { me through hard times. }\end{array}$ & 1 & 7 & 5.05 & 1.265 \\
\hline 18 & $\begin{array}{l}\text { In an emergency, I'm } \\
\text { somebody people } \\
\text { generally can rely on. }\end{array}$ & 1 & 7 & 4.63 & 1.406 \\
\hline 19 & $\begin{array}{l}\text { I can usually look at a } \\
\text { situation in a number of } \\
\text { ways. }\end{array}$ & 1 & 7 & 4.97 & 1.230 \\
\hline 20 & $\begin{array}{l}\text { Sometimes I make myself } \\
\text { do things whether I want } \\
\text { to or not. }\end{array}$ & 1 & 7 & 5.08 & 1.396 \\
\hline 21 & My life has meaning. & 1 & 7 & 5.43 & 1.391 \\
\hline 22 & $\begin{array}{l}\text { I do not dwell on things } \\
\text { that I can't do anything } \\
\text { about. }\end{array}$ & 1 & 7 & 4.77 & 1.354 \\
\hline 23 & $\begin{array}{l}\text { When I am in a difficult } \\
\text { situation, I can usually find } \\
\text { my way out of it. }\end{array}$ & 1 & 7 & 5.00 & 1.273 \\
\hline 24 & $\begin{array}{l}\text { I have enough energy to } \\
\text { do what I have to do. }\end{array}$ & 1 & 7 & 5.21 & 1.358 \\
\hline 25 & $\begin{array}{l}\text { It's okay if there are } \\
\text { people who don't like me. }\end{array}$ & 1 & 7 & 5.48 & 1.463 \\
\hline
\end{tabular}

The minimum, maximum, mean, and standard deviation of the respondents' resilience are shown in the table. Each item on the resilience scale has a minimum value of 1 and a maximum value of 7 . The lowest mean score was 4.12 for the statement "I seldom wonder what the point of it all is" Instead, the statement "I can be on my own if I have to.." received the highest mean score, 5.84 .

Stress

The score values for the respondents' stress levels are shown in the table. According to the findings of the research, the majority of respondents in this survey (72.78 percent or 131 people) had moderate levels of stress, while 21 people (11.67 percent) reported low levels of stress.

Table 4 : Stress Level

\begin{tabular}{llll}
\hline Stress Level & Frequency & Peratus (\%) & Min \\
\hline Low & 21 & 11.67 & \\
Moderate & 131 & 72.78 & \\
High & 28 & 15.56 & \\
Total & $\mathbf{1 8 0}$ & $\mathbf{1 0 0 . 0 0}$ & $\mathbf{1 8 . 7 6}$ \\
\hline
\end{tabular}

Out of 180 participants surveyed, 28 people (15.56 percent) felt depressed. The results of the analysis also found that the mean value of resilience of respondents in this study is 18.76 . 
Table 5: Minimum value, maximum value, mean and standard deviation of stress

\begin{tabular}{|c|c|c|c|c|c|}
\hline No & Item & Minimum & Maximum & Min & SD \\
\hline 1 & $\begin{array}{l}\text { In the last month, how often have } \\
\text { you been upset because of } \\
\text { something that happened } \\
\text { unexpectedly? }\end{array}$ & 0 & 4 & 2.07 & 1.146 \\
\hline 2 & $\begin{array}{l}\text { In the last month, how often have } \\
\text { you felt that you were unable to } \\
\text { control the } \\
\text { important things in your life? }\end{array}$ & 0 & 4 & 1.78 & 1.203 \\
\hline 3 & $\begin{array}{l}\text { In the last month, how often have } \\
\text { you felt nervous and stressed? }\end{array}$ & 0 & 4 & 1.97 & 1.106 \\
\hline 4 & $\begin{array}{l}\text { In the last month, how often have } \\
\text { you felt confident about your } \\
\text { ability to handle } \\
\text { your personal problems? }\end{array}$ & 0 & 4 & 1.59 & .979 \\
\hline 5 & $\begin{array}{l}\text { In the last month, how often have } \\
\text { you felt that things were going } \\
\text { your way? }\end{array}$ & 0 & 4 & 1.86 & 1.015 \\
\hline 6 & $\begin{array}{l}\text { In the last month, how often have } \\
\text { you found that you could not cope } \\
\text { with } \\
\text { all the things that you had to do? }\end{array}$ & 0 & 4 & 1.97 & 1.065 \\
\hline 7 & $\begin{array}{l}\text { In the last month, how often have } \\
\text { you been able to control } \\
\text { irritations in } \\
\text { your life? }\end{array}$ & 0 & 4 & 1.87 & 1.049 \\
\hline 8 & $\begin{array}{l}\text { In the last month, how often have } \\
\text { you felt that you were on top of } \\
\text { things? }\end{array}$ & 0 & 4 & 1.84 & 1.118 \\
\hline 9 & $\begin{array}{l}\text { In the last month, how often have } \\
\text { you been angered because of } \\
\text { things that } \\
\text { happened that were outside of } \\
\text { your control? }\end{array}$ & 0 & 4 & 1.90 & 1.134 \\
\hline 10 & $\begin{array}{l}\text { In the last month, how often have } \\
\text { you felt difficulties were piling up } \\
\text { so high that you could not } \\
\text { overcome them? }\end{array}$ & 0 & 4 & 1.91 & 1.239 \\
\hline
\end{tabular}

The table shows the minimum, maximum, mean, and standard deviation of the respondents'stress levels. Each item on the resilience scale ranges from 0 to 4, with 0 being the lowest and 4 being the most. The lowest mean score was 1.59 for the statement "How often have you felt confident in your ability to overcome personal obstacles in the last 
month?" Instead, the question "How often have you been concerned by things that happened unexpectedly in the recent month?" had the highest mean score of 2.07.

Hypothesis 1: There is a relationship between resilience and stress levels among students throughout the COVID-19 pandemic outbreak.

Table 6: Pearson correlation test results for resilience and stress levels

\begin{tabular}{llll}
\hline & & Resiliency & Stress \\
\hline Resiliency & Pearson & 1 & $-0.254^{* *}$ \\
\hline Stress & Pearson & $-0.254^{* *}$ & 1 \\
\hline $\mathrm{k}<0.01$ & & &
\end{tabular}

The table shows the results of the Pearson correlation test for the relationship between resilience and stress levels among respondents throughout the COVID-19 pandemic outbreak. At the $1 \%$ significance level, the independent variable, resilience, reveals the existence of a correlation link with stress levels. This means that the higher the resilience of adolescents aged 13 to 19 years, the lower the level of stress that will be experienced. The results of Pearson correlation analysis found that the correlation between resilience and stress level was significant $(p<0.01)$. Thus, the hypothesis is accepted. In short, there is strong statistical evidence to conclude that there is a significant relationship between resilience and stress levels of adolescents aged 13 to 19 years throughout the COVID-19 pandemic outbreak.

Hypothesis 2: There is a difference in the level of resilience between male and female students throughout the pandemic outbreak of COVID-19.

Table7: Descriptive statistics for resilience by gender

\begin{tabular}{lllll}
\hline & Gender & Total & Min & SD \\
\hline Resiliensi & Male & 68 & 5.023 & 0.796 \\
& Female & 112 & 5.072 & 0.765 \\
\hline
\end{tabular}

Table 8: Results of Levene test and T- test for resilience levels by gender

\begin{tabular}{|c|c|c|c|c|c|c|}
\hline & \multirow[t]{2}{*}{ Gender } & \multicolumn{2}{|c|}{ Levene Test } & \multicolumn{2}{|l|}{ T-test } & \multirow[b]{2}{*}{ Sig. (dua sisi) } \\
\hline & & $\mathbf{F}$ & Sig. & $\mathbf{t}$ & df & \\
\hline \multirow[t]{3}{*}{ Resiliensi } & Variance are equal & 0.294 & 0.588 & -0.409 & 178.0 & 0.683 \\
\hline & & & & & & \\
\hline & $\begin{array}{l}\text { Variance are not } \\
\text { equal }\end{array}$ & & & -0.405 & $\begin{array}{l}137.1 \\
8\end{array}$ & 0.686 \\
\hline
\end{tabular}

Based on Table 4.15, the Levene test proves that the variance that exists for both data groups is the same $(p=0.588, p>0.05)$. So, the $p$-value and test statistics for the variance assumption are the same will be referred to in this discussion. The results of the independent sample $T$ test analysis showed that there was no mean difference between the resilience of male and female students ( $t=-0.409, p=0.683$ ). Thus, the null hypothesis failed to be rejected $(p>0.05)$ and it can be concluded that the mean for the two samples was not different.

Hypothesis 3: There is a difference between the stress levels of male and female students throughout the pandemic outbreak of COVID-19. 
Table 9: Descriptive statistics for stress levels by gender

\begin{tabular}{lllll}
\hline & Gender & Total & Min & SD \\
\hline Stress & Male & 68 & 1.900 & 0.705 \\
& Female & 112 & 2.131 & 0.631 \\
\hline
\end{tabular}

Table 10: Results of Levene test and T- test for stress levels by gender

\begin{tabular}{llllllll}
\hline & Jantina & & \multicolumn{2}{c}{ Ujian Levene } & Ujian T & \\
& & & F & Sig. & t & df & Sig. (dua sisi) \\
\hline Tekanan & Andaian & varians & 0.481 & 0.489 & -2.281 & 178.0 & 0.024 \\
& $\begin{array}{l}\text { adalah sama } \\
\text { Andaian }\end{array}$ & & & & 0 & \\
& $\begin{array}{l}\text { adalah tidak sama } \\
\text { adalans }\end{array}$ & & -2.220 & 129.5 & 0.028 \\
& & & & 0 & \\
\hline
\end{tabular}

The Levene test, based on Table 4.15, shows that the variance for both data groups is the same $(p=0.489, p>0.05)$. As a result, in this discussion, the $p$-value and test statistics for the variance assumption will be used interchangeably. The findings of the independent sample Ttest analysis revealed that during the pandemic epidemic, there was a mean difference in stress levels between male and female students $(t=2.281, p=0.024)$. As a result, the null hypothesis was successfully rejected $(p=0.05)$, and the mean for the two samples was found to be different.

\section{Disscussion}

Overall, this study reveals that students are under mild stress, but they are resilient during COVID-19 transmission. The findings of this study are also very similar to the findings of a study by Branje \& Morris (2021), who found that during an outbreak, many adolescents experienced increased symptoms of depression, negative effects, and loneliness, as well as lower academic adjustment, especially those who were already at risk before the outbreak. However, the study revealed that they have strong individual, family, and community resources, making them resilient and allowing them to operate even in difficult situations like COVID-19. In Malaysia, the Ministry of Education Malaysia constantly provides online learning modules taking into account to reduce the pressure on students. According to Rathakrishnan et al (2020), teachers continue to deliver a balanced reaction and good service to their students.

The findings of the study also prove that there is a significant negative relationship between stress levels and resilience. Previous research by Ran et al (2020) has shown that resilience has a negative relationship with depression, anxiety disorder, and somatization symptoms. Many school children feel lonely as a result of social distance, which might put them under stress. Friendships and social ties become increasingly important as adolescents get older. Interactions with peers so play a crucial role in the formation of their identities and personalities (Brechwald \& Prinstein, 2011). Teens have been unable to interact and communicate with others at school, as well as participate in physically structured activities, as a result of the lockdown order. This makes it more difficult for teens to acquire social assistance and makes them feel more isolated. According to a study by Alt and colleagues (2021), teenagers with extraversion personalities experienced higher levels of loneliness and stress due to a lack of face-to-face support.

Meanwhile, the independent sample $T$-Test proved that there was a significant mean difference between the stress levels of male adolescents and female adolescents aged 13 to 19 years during this pandemic. The findings of this study support recent research by Morales- 
Rodrguez (2021); Sundarasen et al (2020); Gurvich (2020), which found that female adolescents have higher levels of stress and psychological difficulties than male adolescents. As a result, both parents and teachers must improve their support for female students, as they are more likely to have more pressing issues that require assistance to resolve. According to a study conducted by Magis-Weinberg and colleagues (2021), teenage girls are more prone than boys to be lonely, and they are more likely to have bad online experiences. It is beneficial if learning about resilience is provided as an additional aspect through the PBL technique to have a more effective effect.The study by Danilah (2020) found that students are more active and highly participative during the deliverance of course content in problem Based learning (PBL).

\section{Conclusion}

This survey reveals that stress among Melaka school students is concerning, despite the fact that it is still under control. Many of the social support programmes and campaigns that the government provides and encourages for students help them to be more resilient. As a result, it is necessary for students to always be resilient so that the stress they endure can be better managed and kept at a continuous low level.

\section{References}

Alt, P., Reim, J., \& Walper, S. (2021). Fall from grace: Increased loneliness and depressiveness among extra-verted youth during the German COVID-19 lockdown. Journal of Research on Adolescence, 31(3), 678-891

Amran, M. S., \& Jamaludin, K. A. (2021). The Impact of Unplanned School Closures on Adolescent Behavioral Health During the Covid-19 Pandemic in Malaysia. Frontiers In Public Health, 9, 639041. https://doi.org/10.3389/fpubh.2021.639041

Rathakrishnan, B., George, S., Singh, B. S. S., Kamaluddin, M. R., Wani, M. A. (2020). Burnout among secondary school teachers in Malaysia Sabah. Journal of Xidian University 14: 1530-1536

Branje, S., \& Morris, A. S. (2021). The Impact of the COVID-19 Pandemic on Adolescent Emotional, Social, and Academic Adjustment. Journal of Research on Adolescence, 31, 3, 486-499.

Brechwald, W. A., \& Prinstein, M. J. (2011). Beyondhomophily: A decade of advances in understandingpeer influence processes. Journal of Research on Adolescence, 21, 166179

Chua, Y. P. (2011). Kaedah Penyelidikan. Edisi ke-2. Selangor: Mc Graw Hill Education.

Cohen, S., Kamarck, T., \& Mermelstein, R. (1983). A global measure of perceived stress. Journal of Health and Social Behaviour 24: 385-396.

Danilah, S., Ifa Rizad, M., Hafizah, A. M., Norhaiza, K., Rozainee, K. (2020). Cultivating students' communication skills and psychological well-being through problem based learning (PBL). Jurnal Psikologi Malaysia 34: 159-175

Fauziah, I., Athirah, N. A. Z., Nazirah, H., Ezarina, Z., Khadijah, A. (2020). Mengukur tekanan dan jenis mekanisme penyelesaian masalah dalam kalangan pelajar university. Jurnal Psikologi Malaysia 34: 1-12

Hilwa, A., Jasmeen, N. F. M. B., Maryam, D. M. M. (2020). Relation between smartphone addiction, sleep quality and psychological health among adolescents in Malaysia. International Journal of Psychosocial Rehabilitation. 24: 4288-4298 
Gurvich, C., Thomas, N., Thomas, E. H., Hudaib, A. R., Sood, L., Fabiatos, K., Sutton, K., Isaacs, A., Dan, A. S., Sharp, G. (2020). Coping styles and mental health in response to societal changes during the COVID-19 pandemic. International Journal of Social Psychiatry 4: 115.

Morales-Rodríguez, F. M. (2021). Fear, Strees, Resilience and Coping Strategies during COVID19 in Spanish University Students. Sustainability 13 (11): 1-19. https://doi.org/10.3390/su13115824 [20 Jun 2021].

Ran, L., Wang, W., Ai, M., Kong, Y., Chen, J., dan Kuang, L. (2020). Psychological resilience, depression, anxiety, and somatization symptoms in response to COVID-19: A study of the general population in China at the peak of its epidemic. Social Science and Medicine 262, 113261.

Sundarasen, S., Chinna, K., Kamaludin, K., Nurunnabi, M., Baloch, M. G., Khoshaim, K. B., Abid Hossain, S. F., \& Sukayt, A. (2020). Psychological Impact of COVID-19 and Lockdown among University Students in Malaysia: Implications and Policy Recommendations. International Journal of Environmental Research and Public Health 17(17): 1-13.

Sukor, N. M., Saadah, N. M. A., \& Ezarina, Z. (2019). Sokongan Sosial, Daya Tahan Dan Kesejahteraan Subjektif Remaja Di Institusi Perlindungan Jabatan Kebajikan Masyarakat. e-BANGI, Bangi Vol. 16, Iss. 9: 184-198.

Marchini, S., Zaurino, E., Bouziotis, J., Brondino, N., Delvenne V., \& Delhaye, M. (2020). Study of resilience and loneliness in youth (18-25 years old) during the COVID-19 pandemic lockdown measures. Journal of Community Psychology 2020: 1-13.

Thandevaraj, E. J., Gani, N. A. N., \& Nasir, M. K. M. (2021). A Review of Psychological Impact on Students Online Learning during Covid-19 in Malaysia. Creative Education, 12, 12961306. https://doi.org/10.4236/ce.2021.126097

Wagnild, G., \& Young, H. M. (1993). Development and Psychometric Evaluation of Resilience Scale. Journal of Nursing Measurement 1(2): 165-178.

Magis-Weinberg, L., Gys, C., Berger, E., Domoff, S., \&Dahl, R. (2021). Positive and negative online experiencesand loneliness in Peruvian adolescents during the COVID-19 lockdown. Journal of Research on Adolescence, 31(3), 617-633.

Zaiton, M., \& Balan, R. (2014). Hubungan Daya Ketahanan Dan Sokongan Sosial Terhadap Kesunyian Pelajar Dalam Institusi Pengajian Tinggi. Prosiding Seminar Kebangsaan Integriti Keluarga (SKIK) 2014: 1-12. 